\title{
GIVIL RIGHTS ATTORNEYS' FEES IN CASES RESOLVED ON STATE PENDENT AND FEDERAL STATUTORY GROUNDS
}

\author{
INTRODUCTION
}

\author{
In Alyeska Pipeline Service Co. v. Wilderness Society, ${ }^{1}$ the
} Supreme Court held that federal courts do not have the equitable

1421 U.S. 240 (1975). Alyeska involved a suit by environmental groups against those responsible for constructing the trans-Alaska oil pipeline. The plaintiffs prevailed in the lawsuit, and asserted their right to fees under the "private attorney general" exception to the "American Rule" that each party bears the cost of its own lawyers. That exception had been viewed as supporting a fee award to "any litigant who vindicates an important public interest." Runyon v. McCrary, 427 U.S. 160,182 (1976).

In Alyeska, the Court sharply limited the application of this exception, and expressly criticized its indiscriminate use as a basis for fee awards in "public policy" cases. 421 U.S. at 263 . The general view among the courts of appeals today is that the private attorney general exception has been foreclosed as a basis for a fee award. See, e.g., Skehan v. Board of Trustees, 538 F.2d 53, 59 (3d Cir.), cert. denied, 429 U.S. 979 (1976).

The Supreme Court enunciated the American Rule in Aracambel v. Wiseman, 3 U.S. ( 3 Dall.) 306 (1796) (per curiam). The origin of the rule has been much disputed, with some commentators claiming that it resulted from "accidental statutory history." Ehrenzweig, Reimbursement of Counsel Fees and the Great Society, 54 CALIF. L. Rev. 792, 798 (1966). Others urge that the "popular view of the solitary folk-hero fighting for his rights played a significant role in the emergence of the unique American Rule." Comment, Court Awarded Attorneys' Fees and Equal Access to the Courts, 122 U. PA. L. Rev. 636, 641 (1974) (footnote omitted). Judge Friendly's explanation is the most convincing, pointing out that "the American practice ... was a deliberate departure from the English practice, stemming initially from the colonies' distrust of lawyers and continued because of a belief that the English system favored the wealthy and unduly penalized the losing party." Conte v. Flota Mercante del Estado, 277 F.2d 664, 672 (2d Cir. 1960) (citing Goodhart, Costs, 38 YaLE L.J. 849, 872-77 (1929)).

The "English Rule" to which Judge Friendly refers prevails in most European countries. See generally Rubin \& Stanford, The Sources of South African Law of Costs, 65 S. AFr. L.J. 387 (1948); Goodhart, supra; Sweigert, The Legal System of the Federal Republic of Germany, 11 Hastrings L.J. 7 (1959). Under that rule, the losing party-be it plaintiff or defendant-bears all costs of the litigation, including attorneys' fees. The rationale for the English Rule is that it operates to deter plaintiffs from bringing groundless suits and defendants from defending suits that they probably will not win. Goodhart, supra, at 872 . The rule is administered by "taxing masters," who have unreviewable discretion in setting the fee award. Id. 855.

The different effects of the two rules can be seen by considering a suit in which the claim is colorable and the litigant-plaintiff or defendant-believes that he or she has a fair chance at trial. In England, litigants asserting claims about which they are uncertain run a substantial financial risk. They may decide not to go to court at all, because the threat of being taxed with fees almost raises a presumption against litigation. American litigants, however, have less to lose by proceeding to trial.

The appeal of the American Rule, therefore, is that it offers litigants a fair opportunity to have their day in court and does not discourage presentation of novel 
power to award attorneys' fees for cases brought in the public interest. Rather, the Court concluded, it was for Congress to determine "the circumstances under which attorneys' fees are to be awarded and the range of discretion of the courts in making those awards ...."2

In response to this challenge, Congress enacted the Civil Rights Attorney's Fees Awards Act of $1976^{3}$ (Fees Act), establishing that prevailing parties in an action to enforce various statutory provisions may be awarded fees within the court's discretion. 4 Thus, the Fees Act seeks to encourage private enforcement of Reconstruction Era statutes ${ }^{5}$ outlawing racial discrimination and unconstitutional

legal theories. The rule reinforces the accessibility of American courts to litigants, which Justice Harlan described as "an element of due process" in Boddie 0. Connecticut, 401 U.S. 371,375 (1966). See A.B.A. SEctron OF InT'L and Comp. Law, 1962 Procexedings 117, 118 (Report of Comm. on Comp. Proc. and Prac.) ("it is sincerely the opinion of many practitioners that the right to sue without deterrence by the specter of the possibility of paying an adversary's legal fees is part of our democratic tradition and a bulwark of equality .....").

Proponents of the American Rule also argue that the English Rule affects the poor more severely because the costs of litigation may be very high; that fee shifting creates a subtle conflict of interest because lawyers will seek to please the judge instead of their clients, and that the time expended in calculating fees and difficulties of proof pose burdens for judicial administration. See F.D. Rich Co. v. United States ex rel. Industrial Lumber Co., 417 U.S. 116, 129 (1974); Fleischmann Distilling Corp. v. Maier Brewing Co., 386 U.S. 714 (1967); see also Berger, Coust Awarded Attorneys" Fees: What is "Reasonable"?, 126 U. PA. L. REv. 281, 292 \& n.57 (1977) (collecting cases involving burden on judicial administration).

The rule in the Fees Act is a hybrid of the English and American Rules, providing that prevailing plaintiffs should usually recover fees but that prevailing defendants should recover only in rare cases. The rule therefore provides plaintiffs with an incentive to sue, but provides no such incentive for defendants to defend. This, as one commentator notes, makes the defendant "balance the cost of payment to the plaintiff [in settlement] against the expense of litigating. Defendant's litigation expenses [including fees] afford the plaintiff a legalized form of blackmail." Kuenzel, The Attorney's Fee: Why Not A Cost of Litigation?, 49 IowA L. REv. 75, 78 (1963). Given the preference for plaintiffs central to the Fees Act and the strong tradition of the American Rule, the Act should be viewed as a limited encroachment on, not a legislative abrogation of, the rule.

2421 U.S. at 262.

3 Pub. L. No. $94-559,90$ Stat. 2641 (codified at 42 U.S.C. $\$ 1988$ (1976)).

4 The Act reads in relevant part:

In any action or proceeding to enforce a provision of sections 1981, 1982, 1983, 1985, and 1986 of this title, title IX of Public Law 92-318 [20 U.S.C. 1681 et seq.], or in any civil action or proceedings, by or on behalf of the United States of America, to enforce, or charging a violation of, a provision of the United States Internal Revenue Code, or title VI of the Civil Rights Act of 1964 [42 U.S.C. 2000 d et seq.], the court, in its discretion, may allow the prevailing party, other than the United States, a reasonable attorney's fee as part of the costs.

42 U.S.C. $\$ 1988$ (1976) (brackets in original).

5 The Fees Acts applies to 42 U.S.C. $\$ 1981$ (1976) (prohibiting discrimination in the making and enforcement of contracts); id. $\$ 1982$ (forbidding discrimination in lease and sale of real estate); id. $\$ 1083$ (prohibiting state deprivations of civil 
state action by providing for the payment of attorneys' fees to successful litigants. ${ }^{6}$

The Act has spawned many novel and important issues. ${ }^{7}$ This Comment focuses upon the related questions whether fees should be awarded when a case is decided on a pendent state claim or on federal statutory grounds. Part $I$ examines the use of the civil rights statutes to litigate claims which are federal, but nonconstitutional, and claims which are nonfederal. Part II examines the Fees Act, its legislative history, and its purpose in order to determine Congress's understanding about fee awards for state pendent and federal statutory claims. Part III considers potential eleventh-amendmentrelated sovereign immunity obstacles to fee awards against states on such claims. Part IV suggests two ways in which courts can avoid the potential sovereign immunity problem in these cases; it then concludes that fee awards in pendent and statutory claim cases are not barred by the eleventh amendment.

rights), and id. $\$ 1985$ (proscribing private conspiracies to deprive citizens of equal protection).

${ }^{6}$ See S. Rep. No. 1011, 94th Cong., 2d Sess. 1, reprinted in 1976 U.S. Cone Cong. \& AD. News 5908-09 [hereinafter cited as SENATE RePort]; Note, Promoting the Vindication of Civil Rights Through the Attorney's Fees Awards Act, 80 Coutur. L. Rev. 346, 350 (1980); Comment, Attorney's Fees in Damage Actions Under the Civil Rights Attorney's Fees Awards Act of 1976, 47 U. CrI. L. REv. 332,343 (1980).

7 The language and interpretation of the Act have raised a number of challenging issues for courts and scholars. Defining the prevailing party requirement has been a source of litigation, see, e.g., Bagby v. Beal, 606 F.2d 411 (3d Cir. 1979); Olitsky v. O'Malley, 597 F.2d 303 (1st Cir. 1979), and commentary, see Note, Promoting the Vindication of Civil Rights Through the Civil Rights Attorney's Fees Awards Act, 80 Colum. L. Rev. 346 (1980); Comment, Attorney's Fees in Damage Actions Under the Civil Rights Attorney's Fees Awards Act of 1976, 47 U. Chr. L. Rev. 332 ( 1980 ).

Recent decisions and commentary have dealt with immunity under the Act. See Supreme Court of Va. v. Consumers Union of the United States, Inc., 446 U.S. 719 (1980) (upholding immunity of Virginia judiciary because acting in legislative role in regulating state bar); Morrison v. Ayoob, 627 F.2d 669 (3d Cir. 1980) (per curiam) (no immunity for judicial officers acting in official capacity), cert. denied, 101 S. Ct. 898 (1981); Note, Hutto v. Finney: State's Eleventh Amendment Immunity Substantially Reduced, 10 U. ToL. L. Rev. 541 (1979); Note, Sovereign Immunity Bars Awards of Attorney's Fees Against the United States in Action Under Title VI, 24 VIr. L. REv. 242 (1979).

Commentators have also examined the methods of fee calculation, see Comment, Calculation of a Reasonable Award of Attorney's Fees Under the Attorney's Fees Awards Act of 1976, 13 J. MAR. L. Rev. 331 (1980), and the question when fees can be awarded and for what proceedings, see Comment, Interim Awards of Attorney's Fees Under the Civil Rights Attorney's Fees Awards Act of 1976, 21 Aruz. L. Rev. 893 (1979).

One writer has examined the Act's applicability to substantive litigation. Wolf, Pendent Jurisdiction, Multi-Claim Litigation, and the 1976 Civil Rights Attorney's Fees Awards Act, 2 W. NEw ENG. L. Rev. 193 (1979). 


\section{Use of Givil Rights Laws to Present \\ Nonconstitutional Claims}

\section{A. Pendent Claims}

Since the decision in Osborn v. Bank of the United States, ${ }^{8}$ it has been accepted that federal courts have the power to decide all questions presented by a case. This doctrine, loosely known as pendent jurisdiction, permits federal courts to decide cases on both state grounds and nonjurisdictional federal grounds, provided that those grounds are properly tied to a jurisdictional federal ground. ${ }^{9}$

The Court defined the necessary link between these claims in United Mine Workers $v$. Gibbs, ${ }^{10}$ holding that federal courts have constitutional power to decide pendent claims when "[t]he state and federal claims ... derive from a common nucleus of operative fact .... [And a plaintiff] would ordinarily be expected to try them all in one judicial proceeding ...."11 But the power recognized by the Gibbs Court is discretionary, subject to the trial court's "considerations of judicial economy, convenience, and fairness to litigants." 12

Pendent jurisdiction most narrowly defined would include only the federal court's ability to hear and decide state law claims related to federal claims. ${ }^{13}$ Such claims could be asserted in tandem

822 U.S. ( 9 Wheat.) 738 (1824). Chief Justice John Marshall's opinion stated "when a question to which the judicial power of the Union is extended ... forms an ingredient of the original cause, it is in the power of Congress to give the [lower] Courts jurisdiction of that cause, although other questions of fact or of law may be involved in it." Id. 823 .

- See generally C. Wright, Law of Federal Courts $\$ 19$ (2d ed. 1970).

10383 U.S. 715 (1966).

$11 I d .725$.

12 Id. 726. The Court listed a number of factors to be considered in deciding whether to hear pendent claims, including avoidance of unnecessary decisions of state law, pretrial dismissal of the federal claims, predominance of the state issue, and presentation of federal policy claims. See id. 726-27.

It can be contended that the Gibbs test, stemming from judicial concern for expediting the resolution of disputes based on the same facts, is altogether inappropriate for fee cases. This argument is based upon the premise that the Fees Act is aimed at encouraging enforcement of substantive civil rights, so the Gibbs policies do not come into play. This argument, however, has failed to persuade the Supreme Court. Compare Edelman v. Jordan, 415 U.S. 651, 653 n.I (1974) with Maher v. Gagne, 448 U.S. 122, 127 (1980). But of. Note, The Concept of Law-Tied Pendent Jurisdiction: Gibbs and Aldinger Reconsidered, 87 Yare L.J. 627, 648 (1977) (arguing Gibbs test may be unconstitutional).

13 See C. Wricht, supra note 9, at 65. ("Pendent jurisdiction, as the term [is] used in this section, refers only to the joinder of state and federal claims ...."). 
with federal constitutional questions, federal statutory questions which confer jurisdiction on the district court, or both. ${ }^{1 *}$

But pendent jurisdiction is not normally confined to this narrow meaning. Rather, the term is also used to identify cases in which a federal statutory claim that does not confer jurisdiction on the federal court is attached to a statutory claim that confers jurisdiction, ${ }^{15}$ or to a constitutional claim. ${ }^{16}$ This broad definition was the foundation of the Supreme Court's recent analysis of the constitutionality of a Fees Act-based award for pendent claims. ${ }^{17}$

That case, Maher v. Gagne, held that a Social Security Act claim "pendent" to due process and equal protection claims supported a fee award. The Court, considering the sovereign immunity question that looms large when the narrow definition of pendent claims is considered," ${ }^{18}$ stated that "Congress was acting within its enforcement power in allowing the award of fees in a case in which the plaintiff prevails on a wholly statutory, non-civil-rights claim pendent to a substantial constitutional claim ...."19 Even before this sweeping dicta, lower federal courts had resolved the "pendent claim" issue involving state claims by awarding fees any time the plaintiff had not lost on the merits of the federal claim. ${ }^{20}$ The Maher dicta can-

14 See, e.g., Jackson v. Stinchcomb, 635 F.2d 462 (5th Cir. 1981) (state claim pendent to first amendment claim); Network Project v. Corporation for Public Broadcasting, 561 F.2d 963 (D.C. Cir. 1977), cert. denied, 434 U.S. 1068 (1978) (same); Till v. Unifirst Federal Savings \& Loan Ass'n, 653 F.2d 152, 161 n.24 (5th Cir. 1981) (state claim pendent to National Flood Insurance Act); City of S. Pasadena v. Goldschmidt, 637 F.2d 677 (9th Cir. 1981) (state claim pendent to NEPA and Federal-Aid Highway Act).

15 See Riker Laboratories, Inc. v. Gist-Brocades N.V., 636 F.2d 772, 780 n.2 (D.C. Cir. 1980) (antitrust, patent, and declaratory judgment claim).

16 See, e.g., Miller v. Youakim, 440 U.S. 125, 132 (1979) (Social Security Act claim); Hagans v. Lavine, 415 U.S. 528, 532-36 (1974) (same); Davis v. Reagen, 630 F.2d 1299, 1301 (8th Cir. 1980) (same).

17 Maher v. Gagne, 448 U.S. 122 (1980).

18 See supra note 13 and accompanying text.

19448 U.S. at 132.

20 See Haywood v. Ball, 634 F.2d 740 (4th Cir. 1980) (state law negligence claim pendent to $\S 1983$ and fourteenth amendment claims; fees denied because plaintiff lost on merits of constitutional claim); Doe v. Marshall, 622 F.2d 118 (5th Cir. 1980) (fees awarded without discussion of merits after claim mooted); Reproductive Health Servs. v. Freeman, 614 F.2d 585 (8th Cir.) (fees awarded although plaintiff lost on constitutional claim), vacated, 449 U.S. 809 (1980); Kimbrough v. Arkansas Activities Ass'n, 574 F.2d 423, 427 (8th Cir. 1978) (court disposed of claim on grounds relating to challenged regulation's ambiguousness instead of fourteenth amendment claims; fees awarded); Seals v. Quarterly County Court, 562 F.2d 390 (6th Cir. 1977) (state voting rights claim pendent to fourteenth amendment claims; fees awarded); Bass v. Spitz, 522 F. Supp. 1343 (E.D. Mich. 1981) (state malicious prosecution claim pendent to fourteenth amendment claim; fees denied because plaintiff lost on merits of constitutional claim); Russo v. New York, 515 F. Supp. 470 (S.D.N.Y. 1981) (malicious prosecution and fourteenth amendment claims; fees awarded although plaintiff lost on consti- 
not help but expand that trend. Yet, as this Comment demonstrates, Maher did not resolve the question whether fees may be awarded when plaintiffs prevail solely on state pendent claims, and the lower courts' holdings that fees are appropriate in such cases present constitutional questions as well as difficulties of judicial administration.

\section{B. Federal Statutory Claims}

Since the passage of the Fees Act, federal courts have awarded fees to plaintiffs prevailing on statutory claims pendent to substantial constitutional claims. ${ }^{21}$ This trend will certainly be reinforced by the Supreme Court's decision in Maine $v$. Thiboutot, ${ }^{22}$ wherein the Court considered the scope of section 1983 and of the Fees Act.

The Court first held that section 1983 is not limited to providing causes of action for claims arising under the constitution or "some subset of [civil rights] laws." ${ }^{23}$ Instead, six justices agreed that section 1983 provides a remedy for "violations of federal statutory as well as constitutional law." 24 The Court then held that section 1988 allows an award of fees "in any $\S 1983$ action." 25 Thus, the Court has plainly held that federal statutory claims enforced through section 1983 permit a fee award.

Because lower courts view fee awards as almost mandatory when plaintiffs prevail, ${ }^{26}$ the Thiboutot holding essentially means that any plaintiff prevailing on any section 1983 claim is entitled to fees. This Comment suggests that Congress probably intended fee awards in cases vindicating statutory claims, and that the eleventh amendment does not bar awards in such cases.

tutional claim); Meriwether v. Sherwood, 514 F. Supp. 433 (S.D.N.Y. 1981) (fourteenth amendment, state law negligence, and malpractice claims; fees denied because plaintiff lost on constitutional claim); Williams v. Thomas, 511 F. Supp. 535 (N.D. Tex. 1981) (civil rights and state assault and battery claims; fees awarded; plaintiff prevailed on both claims); Anderson v. Redman, 474 F. Supp. 511 (D. Del. 1979) (state claim and fourteenth amendment claim; fees awarded; constitutional claim not reached).

21 See, e.g., Bond v. Stanton, 555 F.2d 172 (7th Cir. 1977), cert. denied, 438 U.S. 916 (1978) (Social Security Act); White v. Beal, 447 F. Supp. 788 (E.D. Pa. 1978) (same); La Raza Unida v. Volpe, 440 F. Supp. 904 (N.D. Cal. 1977) (Uniform Relocation Assistance \& Real Property Acquisition Policies Act, Dept. of Transportation Act, Federal-Aid Highway Act); Southeast Legal Defense Group v. Adams, 436 F. Supp. 891 (D. Or. 1977), aff'd, 657 F.2d 1118 (9th Cir. 1981) (Federal-Aid Highway Act).

22448 U.S. 1 (1980).

23 Id. 4. The Court held that $\$ 1983$ 's "plain language" included all "laws," because "Congress attached no modifiers to the phrase [rights, privileges, or immunities secured by the Constitution and laws]." Id.

$24 I d$.

25 Id. 9 (emphasis in original).

26 See, e.g., Gates v. Collier, 616 F.2d 1268, 1275 (5th Cir. 1980) (fees should be awarded almost "as a matter of course"). 


\section{Interpreting the Scope of the Fees. Act}

While there may be constitutional limitations to Congress's power to award fees in cases involving pendent and statutory claims, that question need only be considered if those who enacted the Fees Act intended it to apply to such cases. To determine whether Congress gave guidance-about its view of the Fees Act's scope, it is necessary to consider the plain language of the statute, the legislative history, and Congress's purpose in passing the statute. ${ }^{27}$

\section{A. Plain Language}

The plain language of the Fees Act gives no indication that Congress expected pendent claims to trigger fee awards. The statute states only that fees may be awarded "[i]n any action or proceeding to enforce sections 1981, 1982, 1983, 1985, and 1986 of this title ...."28 Because state claims cannot be said to "enforce" any of these statutes, it seems logical to conclude that such claims cannot serve as the basis for fee awards. But, despite the appeal of the argument that Congress meant to exclude what it did not include, other fragments of the inquiry into congressional intent point to the opposite conclusion. ${ }^{29}$

Federal statutory claims also seem to present a straightforward question. Congress included only five statutes in the Fees Act's coverage, ${ }^{30}$ and the enumeration of those statutes should exclude all others. But the Court's dramatic expansion of section 1983's reach in Maine $v$. Thiboutot ${ }^{31}$ likewise expanded the Fees Act's applicability. After Thiboutot, the Act's plain language clearly includes all federal statutory claims "enforced through" section 1983.

In Thiboutot, the Court emphasized that "fees are available in any $\S 1983$ action. ... [T] [ here can be no question that Congress passed the Fees Act anticipating that it would apply to statutory

27 These three sources are traditionally considered in studying legislation. See Comment, Eliminating Sex Discrimination in Educational Institutions: Does Title IX Reach Employment?, 129 U. PA. L. REv. 417 (1980).

2842 U.S.C. $\$ 1988$ (1976).

29 As a general rule, plain language should be determinative in statutory interpretation. See Tennessee Valley Auth. v. Hill, 437 U.S. 153, 184 n.29 (1978); Camminetti v. United States, 242 U.S. 470 (1917). But this adage is by no means binding on courts seeking to interpret the statute. See, e.g., Maine v. Thiboutot, 448 U.S. 1, 9 (1980) (" $t]$ he legislative history is entirely consistent with the plain language.").

30 See supra note 4.

31448 U.S. 1 (1980). See supra notes $22-25$ and accompanying text. 
\$ 1983. clains." 32 Given the Court's use of legislative history to support the "plain language" argument, it is appropriate to consider the legislative record surrounding passage of the Act for guidance about the Act's intended scope.

\section{B. Legislative History}

\section{Pendent Claims...}

The House explicitly approved fee awards for plaintiffs prevailing on state pendent claims. The House Report states:

In some instances . . . the claim with fees may involve $a$ constitutional question which the courts are reluctant to' resolve if the non-constittuional [sic] claim is dispositive. Hagans $v$. Lavine, 415 U.S. 528 (1974). In such cases, if the claim for which fees may be awarded meets the "substantiality" test, see Hagans v. Lavine, supra; United Mine Workers v. Gibbs, 383 U.S. 715 (1966), attorney's fees may be allowed even though the Court declines to enter judgment for the plaintiff on that claim, so long as the plaintiff prevails on the non-fee claim arising out of a "common nucleus of operative fact." United Mine Workers v. Gibbs, supra at $725 .^{33}$

The explicitness of this statement has persuaded even the Supreme Court to end the state pendent claim inquiry there. ${ }^{34}$ But the Senate's view of the bill could support a contrary result.

32448 U.S. at 9-10 (emphasis in original).

33 H.R. Rep. No. 1558, 94th Cong., $2 d$ Sess. 4 n.7 (1976).

34 Maher v. Gagne, 448 U.S. 122, 132 \& n.I5 (1980).

Examination of the Fees Act's legislative history is complicated by the unusual manner in which the bill was enacted. Senator John Tunney introduced the Senate bill, S. 2278, on August 1, 1975. 121 CoNG. Rec. 26,777 (1975). Representative Robert Drinan introduced the House version, H.R. 9552, on September 15 of. the same year. Id. 28,607 .

The Senate Judiciary Committee reported S. 2278 on June .29, 1976, 122 Cong. Rec. 12,317 (1976), but debate on the bill did not begin until September 21,1976, id. 31,470 .

Meanwhile, the House bill was reintroduced as H.R. 15460 on September S, 1976, id. 29,274, and reported by voice vote of the Judiciary Committee on September 15, id. 30;556. At this point the House bill was identical to the Senate version. Id. 35,122 (Statement of Rep. Drinan). The bill was placed on the House suspension calendar for consideration on -September 21, but was not reached on that day. Id.

With both houses of Congress racing to adjourn by October 1 in order to allow a month for campaigning before the November election, the House's failure to consider the bill on September 21 portended failure for the Fees Act. The floor managers of the two bills therefore agreed to pass the Senate bill in both houses in order to avoid a conference. Conferences between the two houses generally 
Debate in the Senate focused on the bill's applicability to "civil rights" claims. The Senate Report expressly states that the bill "is limited to cases arising under our civil rights laws . . . ." 35 Senator Kennedy, a principal sponsor of the legislation, ${ }^{36}$ stressed that "the availability of fees awards [should] be expanded to encompass all major Federal civil rights laws. Not just a select fewchosen through historical accident-but all the civil rights laws of this country ...." 37 He later added:

The purpose of this bill is to aid civil rights. Before the Alyeska.case ... . the Federal courts throughout the country were ... awarding attorneys' fees under the statutes included in this bill. ... In Alyeska the Supreme Court said that, no matter how beneficial that practice might be in certain areas of the law, only Congress ... had the power to decide which areas of the law deserved the additional inducement of attorneys' fees for enforcement. Civil rights is one of those areas. ${ }^{38}$

The difficulty with limiting the Fees Act's application to civil rights is that Congress never expressed its view about what cases came under that rubric. For example, several statements view the Act as applying only to cases brought to vindicate constitutional

settle differences in versions of the bill, and often issue reports to clarify ambiguities in the legislative history.

In the Senate, James Allen of Alabama opposed the bill and, even after cloture, attempted to stall passage of the measure by introducing and demanding a vote on scores of amendments. The Senate finally agreed to an amendment providing for awards to prevailing taxpayers in suits brought by the Internal Revenue Service. Id. 33,311-12. In return, Allen promised that "[i]f this amendment is adopted, [I] ... will call up no further amendments, will make no further statements with respect to the bill." Id. 33,311.

The Senate passed S. 2278 on September 29, 1976. Id. 33,315. The House made consideration of the Senate bill, identical to H.R. 15460 in every respect except the Allen amendment, id. 35,122 (Remarks of Rep. Drinan), possible by special order of the Rules Committee on September 30. Id. 34,322. That order forbade amendments to the bill, and the House passed the Senate bill after one hour of debate, see id. $35,121-29$, on October 1, 1976-the last day of the 94th Congress. Id. 35,130. Given the somewhat frantic rush to pass the Fees Act, the legislative history may be less than clear about what issues the legislators considered, and how they intended those issues to be resolved.

85 Senate Repont, supra note 6, at 4, reprinted in 1976 U.S. Cone Cong. \& AD. NEws, 5908, 5912.

${ }^{36}$ See 122 CoNc. Rec. 31,471 (1976) (Kennedy substitute for Tunney bill); cf. id. 31,850 (amendment by Sen. Allen to entitle bill "Tunney-Kennedy Civil Rights Attomeys Relief Act of 1976).

37 Id. 31,472 .

38 Id. 33,314 (emphasis added). 
rights. ${ }^{39}$ Yet the legislation's sponsors explicitly drew a distinction between "civil" and "constitutional" rights, explaining that both were to be a proper basis for fee awards.40

The Senate debates and report do not directly refer to the pendent claim problem. The Senate, however, referred to the House Report for clarification on another substantive point.41 And the House debates on the substitute Senate bill explicitly stated that body's understanding that the House Report would be authoritative in interpreting the Act. ${ }^{42}$

In short, the legislative history leans toward allowing fees in cases resolved on pendent state grounds. But the answer is far from clear.

\section{Federal Statutory Claims}

The debates leading to the Fees Act's passage indicate that the bill's sponsors anticipated that fees would be awarded in a broad range of cases involving federal statutory claims. Representative Drinan, the bill's principal sponsor, made clear that his view of the Act's scope was quite broad. In discussing the Senate substitute eventually adopted by the House, Representative Drinan explained each of the statutes covered by the Act. He stated: "Section 1983 authorizes suits against State and local officials based upon Federal statutory rights as well as constitutional rights. For example, Blue against Craig, 505 F.2d 830 (4th Cir. 1974)." 43

The Senate Report also viewed section 1983 as "redressing violations of the Federal Constitution or laws by officials sworn to uphold the laws." 4i Indeed, Senator Kennedy's lengthy list of fee cases includes one statutory cause of action among a list of examples focusing on claims traditionally viewed as "pure" civil rights actions. ${ }^{45}$

39 See, e.g., id. 35,128 (Statement of Rep. Seiberling) ("violations of the Constitution").

40 See id. 35,118 (Statement of Rep. Seiberling) ("civil and constitutional rights"); id. 35,126 (Statement of Rep. Kastenmeier) ("constitutional and statutory rights"); id. 35,122 (Statement of Rep. Drinan) ("Federal statutory as well as constitutional rights").

41 Id. 33,312 (Statement of Sen. Kennedy).

42 Id. 35,122 (Statement of Rep. Drinan).

43 Id. Blue involved a claim that North Carolina's Medicaid plan was inconsistent with the Social Security Act.

44 Senate Report, supra note 6, at 4, reprinted in 1976 U.S. Code Cońg. \& Ad. News 5908, 5911 (emphasis added).

45122 Cong. REc. 33,314 (1976). 
The Senate Report also includes a footnote listing several cases in'which fees were awarded before Alyeska, and that footnote includes "a wide variety of race and non-race cases, such as cases involving . . enforcement of federal statutory rights under, e.g., welfare, urban renewal, and highway relocation laws." 46

: . In short, the intention of the principal sponsors of the Act in permitting fees under section 1983 appears to have comprehended the decision in Thiboutot, and fee awards against the states based on federal statutory claims seem to follow their expressed intent.

\section{Congressional Purpose}

Because the plain language and the legislative history of the Fees Act, at least with respect to state pendent claims, are inconclusive, it is appropriate to consider whether awarding fees in cases resolved on state pendent or federal statutory grounds is consistent with the Act's purpose. This, as Professor Cox has noted, involves determining the "general aim or policy which pervades a statute." 17

The Fees Act seeks to encourage private enforcement of civil rights by insuring that the cost of legal counsel will not deter plaintiffs with legitimate grievances from filing suit. ${ }^{48}$ It seeks to fill the gap in attorneys' fees awards in civil rights cases left by the Court's decision in Alyeska.49 Yet the stumbling block is again the meaning to be attached to the words "civil rights."

If civil rights include only constitutional rights, ${ }^{50}$ then pendent and statutory claims cannot appropriately give rise to fee awards.

46 Staff of Subcomm. on Constitutional Rrghts of the Senate Comm. on the Judictary, 94te Cong., 2d Sess., Sounce Book [For the] Crvil Rughts Atrorney's Fees Awards ACt of 1976, at 291 \& n.3 (Comm. Print 1976) (listing cases referred to in SENATE Repont, supra note 6, at $4 \mathrm{n.3}$, reprinted in 1976 U.S. Code Cong. \& AD. News 5908, 5912 n.3).

47 Cox, Judge Learned Hand and the Interpretation of Statutes, 60 Harv. L. Rev. 370, 370 (1947).

48 See, e.g., Senate Report, supra note 6, at 4, 6, reprinted in 1976 U.S. Code Conc. \& AD. News 5908, 5911, 5913; H.R. Rep. No. 1558, 84th Cong., 2d Sess. 1 (1976).

49 See, e.g., 122 Conc. Rec. 35,126 (1976) (Statement of Rep. Seiberling); SENATE REpoRT, stpra note 6, at 4, reprinted in 1976 U.S. Code Cong. \& AD. NEwS 5908, 5912 .

50 One courageous scholar ventures a definition of "civil rights" by contrasting "civil liberties":

The usual illustrations [of civil liberties] are the freedoms of religion, speech, the press and assembly. The other individual prerogatives, those protected against state action with supplementary enforcement powers granted to the federal government, are known as "civil rights". The best illustration of these is the right to vote.

... In summary, civil liberties protect the individual against his government-local, state, and national. Civil rights protect individuals 
Social security, for example, is not a constitutional right. . Indeed, the Social Security Act is not even a statute guaranteeing equal. rights. ${ }^{51}$ Similarly, a prisoner's demand for nonnegligent medical care by police or county hospitals would not rise to the level of a constitutional "civil right."

But if civil rights means individual rights protected by law, ${ }^{62}$ then the examples just noted could be classified as civil rights. For example, a discharged employee might join a state law claim of wrongful discharge to a section 1981 claim. A court resolving the case only on state grounds would be hard pressed to hold that the plaintiff had failed to vindicate civil rights, so fees would seem. appropriate.

It is worth noting in examining congressional purpose that the Act "could not be broader." 53 Given its broad purposes of insuring access to courts and restoring fee award law to its pre-Alyeska status, the Act suggests a broad reading of civil rights. This suggests that fees should be awarded in both state pendent and federal statutory cases.

\section{Summary}

The plain language and legislative history suggest that fee awards may be appropriate for federal statutory claims. The statute's purpose also seems to support this view. Thus, the Court's resolution of Thiboutot seems correct; but its care in reserving the question in Maher indicates that there may be an important distinction between "civil rights" and "non-civil-rights claims." The waters are also murky on the state pendent claim issue. On balance, it is the statute's broad purpose more than the fragments of

against individuals and government officials in discriminating practices based upon color, creed or national origin.

R. Storex, Our Unatmanable Rughts 33, 35 (1965). The distinction Storey draws between civil rights and civil liberties is supported by other scholars. See J. TEN Broex, The ANTISLavery Origins of the Fourteenth AMENDMENT 159 (1951) ("The common denominator [in enacting the fourteenth amendment] settled in [people's] minds by thirty years of abolitionist proselytization as the basis for a means of achieving Negro rights, was thus the concept of the equal protection of the laws for [people's] civil, that is, natural rights."); of. E. NEwMAN, CrvI LmERTY AND CTVIL RrGHTS 81 (6th ed. 1979) (calling the 13th, 14th, and 15th amendments the "Civil Rights" amendments).

51 See Chapman v. Houston Welfare Rights Org., 441 U.S. 600 (1879).

52 See Oregon v. Mitchell, 400 U.S. 112, 163 (1970) (Harlan, J.) ("privileges of [being] citizen[s].").

ss Hutto v. Finney, 437 U.S. 678, 694 (1978). 
legislative history that suggests that fee awards in state pendent claim cases are appropriate. It is, therefore necessary to consider the sovereign immunity objection to such awards.

\section{The SOVEREIGN IMMUNITY LIMITATION ON THE SCOPE OF THE Fees Act}

\section{A. Background}

The only constitutional argument against the Act is that fee awards in cases decided on pendent state or federal statutory grounds infringe the states' sovereign immunity, guaranteed by the eleventh amendment. ${ }^{54}$ To protect the Act from such a challenge, Congress explicitly stated that it enacted the Act pursuant to its power to enforce the fourteenth amendment. ${ }^{55}$

The proposition that the enforcement power of the fourteenth amendment can override the eleventh amendment's guarantee of sovereign immunity was established in Fitzpatrick $v$. Bitzer. ${ }^{56}$ In that case the Court held that by specifically providing in the statute for attorneys' fees in title VII suits, Congress evidenced its intent to dispense with eleventh amendment immunity. ${ }^{57}$ The Court reasoned that " the Constitution now expressly gives authority for congressional interference and compulsion in the cases embraced within the Fourteenth Amendment." " 58 Because of that express authority, the Court found that the eleventh amendment "and the principles of state sovereignty which it embraces, are necessarily limited by the enforcement provisions of $\S 5$ of the Fourteenth Ámendment." 59

Fitzpatrick, then, held that the fourteenth amendment's limitations on state authority gives Congress plenary power in enforcing the amendment. That plenary power, provided that it is explicitly

54 The eleventh amendment provides: "The Judicial power of the United States shall not be construed to extend to any suit in law or equity, commenced or prosecuted against one of the United States by Citizens of another State, or by citizens or Subjects of any Foreign State." U.S. CoNST. amend. XI. The amendment. also bars suits by citizens of a state against that state. Hans v. Louisiana, 134 U.S. 1 (1890).

55 Senate Report, supja note 6, at 5, reprinted in 1976 U..S. Code Conc. \& AD. News 5908, 5913. See 122 Cong. Rec. 35,123 (1976) (Statement of Rep. Drinan).

58427 U.S. 445 (1976).

57 Id. 457.

58 Id. 455 (quoting Ex Parte Virginia, 100 U.S. 339, 348 (1880)).

89 Id. 456 (citation omitted). 
and appropriately employed, is sufficient to overcome rights reserved. to the state by other constitutional provisions. ${ }^{60}$

The Fees Act itself faced an eleventh amendment challenge in Hutto v. Finney. ${ }^{61}$ In that case, the attorney general of Arkansas argued that the eleventh amendment barred a fee award to prisoners who prevailed against the state on eighth amendment claims. The attorney general's argument was based largely upon the proposition that sovereign immunity could not be abrogated without express language in the body of the statute.

The Court rejected the "clear statement" 62 argument for three reasons. First, the majority considered the plain language of the statute and held that "the Act itself could not be broader." 63 Second, the Court found that the legislative history supported abroga: tion of eleventh amendment immunity. ${ }^{84}$ Third, the Court concluded that Congress's rejection of amendments designed to insure state government immunity from fee awards expressed its intent "in deeds as well as words." вs The Court's holding, in short, was that "plain indications of legislative intent" to utilize the enforcement power and to override sovereign immunity were sufficient to overcome the eleventh amendment..$^{66}$

The Court, however, also discussed fee awards in terms of litigation costs, adopting Justice Stevens' separate views in Fitzpatrick. ${ }^{67}$ It is unclear whether this cost argument was meant to be an alternative basis for the Hutto decision or merely a supporting rationale for the argument that fee awards were not "retroactive liability" against the states, the imposition of which was forbidden by the Court's decision in Edelman $v$. Jordan. ${ }^{68}$ At any rate, the dissenters viewed

${ }^{60}$ See Pennhurst State School \& Hospital v. Halderman, 101 S. Ct. 1531, 1539 (1981) ("[W]e should not quickly attribute to Congress an unstated intent to act under its authority to enforce the Fourteenth Amendment. [In o] ur previous cases ... Congress . . . expressly articulated its intent to legislate pursuant to \$5.").

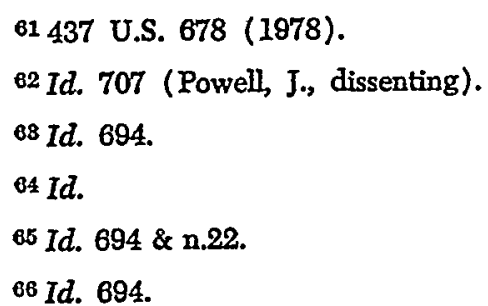

67 Id. 695-98. See Fitzpatrick v. Bitzer, 427 U.S. 445, 460 (1976) (Stevens, J., concurring in the judgment); infra notes 160-68 and accompanying text.

68415 U.S. 651 (1974). 
this argument as an alternative ground of decision, ${ }^{69}$. and took issue with the contention that fees could properly be considered costs.

- Justice Rehnquist added. a separate dissent. ${ }^{70} \mathrm{He}$ argued that Fitzpatrick's rationale was not appropriate for Hutto because the former case involved a conceded equal protection violation while the latter involved an eighth amendment claim. ${ }^{71}$. The eighth amendment, however, does not apply to the states by its terms, and Justice Rehnquist noted that "it is not at all clear to me that ... Congress has the same enforcement power under $\$ 5$ with respect to a constitutional provision which has merely been judicially incorporated' into the Fourteenth Amendment that it has with respect to a provision which was placed in that amendment by the drafters." 72

This distinction reappeared in the unanimous portion of the Court's opinion in Maher $v$. Gagne. ${ }^{73}$ The state there argued that because Hutto involved a constitutional violation, its rationale was not relevant to the statutory claim asserted in Maher. ${ }^{74}$ Of course, the Court had already held that the constitutional claim in Maher remained in the case for long enough to support a fee award. ${ }^{75}$ But the Court answered the argument that Hutto was inapplicable by stating:

[A]s Mr. Justice ReHnquist noted in his dissent, the underlying claim in Hutto was predicated on the Eighth Amendment as made applicable to the States by the Fourteenth Amendment rather than on any substantive provision of the Fourteenth Amendment itself. The prisoners' claim in Hutto was therefore arguably more analogous to the statutory claim involved in this case than to the constitutional claims asserted here or to the equal protection claim asserted in Fitzpatrick v. Bitzer. ${ }^{78}$

Despite the apparent import of this dicta, the Court expressly reserved the question whether "a federal court could award attorney's

69437 U.S. at 707-08 (Powell, J., dissenting).

70 Id. 710-18.

71 Id. 717. Justice White joined this portion of the opinion.

72 Id. 717-18.

73448 U.S. 122 (1980).

74 Id. 133: n.16.

75 Id. 131.

70 Id. 133 n.16 (citations omitted). 
fees against a State based on a statutory, non-civil-rights claim." 77 It is to that question that this Comment now turns.

\section{B. The Scope of the Enforcement Power}

Requests for fees in statutory, non-civil-rights cases essentially present the question whether Congress can use the enforcement power of the fourteenth amendment to create a "remedy" for a substantive "right" not conferred by the Constitution. It is therefore necessary to consider the Court's pronouncements about the limits of congressional power under section 5 .

Professor Cox described the enforcement power of the fourteenth amendment as "a vast untapped reservoir of federal legislative power to define and promote the constitutional rights of individuals in relation to state government." 78 That power, which had "lain neglected for almost a century[,]" 79 was first employed in modern times to override a New York literacy test that arguably discriminated against Puerto Ricans.

Katzenbach v. Morgan ${ }^{80}$ was a challenge by New York election officials to the constitutionality of the section of the 1965 Voting Rights Act striking down literacy tests when applied to persons educated in schools in which the "predominant classroom language [is] other than English . . . " 81 In upholding the constitutionality of that section, seven members of the Court joined Justice Brennan's opinion that, for the first time, tried to define the substantive limits of the enforcement power.

Morgan was understood by one Justice to have held that "division of power between state and national governments, like every provision of the Constitution, was expressly qualified by the Civil War Amendments' ban on racial discrimination." 82 In the context of remedying discrimination against Puerto Ricans, this observation required the Court to hold that the enforcement power's reach was identical to that of the necessary and proper clause. Thus, the Court's test for analyzing the proper use of the enforcement power, "as in all cases concerning the express powers of Congress with rela-

77 Id. 130.

78 Cox, The Supreme Court 1965 Term-Foreword: Constitutional Adjudication and the Promotion of Human Rights, 80 Hanv. L. Rev. 91, 99 (1966).

79 Id. 101.

80384 U.S. 641 (1966).

8142 U.S.C. $\$ 1973 \mathrm{~b}(\mathrm{e})$ (1976).

82 Oregon v. Mitchell, 400 U.S. 112, 129 (1970) (Black, J.). 
tion to the reserved powers of the States," 83 was that expounded by Chief Justice John Marshall in McCulloch v. Maryland. ${ }^{84}$

The Court interpreted the McCulloch test to require two inquiries. First, were the objectives addressed by the challenged legislation within Congress's power? Second, was the means Congress used consistent with the Constitution? The Court held in Morgan that the Act secured for the Puerto Rican community nondiscriminatory treatment by government in voting and in provision and administration of governmental services, satisfying the first inquiry. The Court then held that it was not necessary to assess and weigh the various conflicting considerations, or Congress's resolution of those considerations. The second prong of the Morgan test was satisfied by the mere decision that the Court could "perceive a basis upon which Congress might resolve the conflict as it did." 85

After Morgan resurrected the enforcement power as a useful tool for federal legislation, Congress began advancing section $\mathbf{5}$ as a basis for a series of controversial legislative actions. In Oregon $v$. Mitchell, ${ }^{86}$ the enforcement power was said to support Congress's power to lower the voting age in state elections-a proposition rejected by a narrow majority of the Court. Yet an equally narrow majority held that the power did permit Congress to lower the voting age in federal elections. ${ }^{87}$ In Fullilove $v$. Klutznick, ${ }^{88}$ the Court concluded, albeit without a single opinion, that the enforcement power gave Congress the right to set aside a percentage of government contracts for minority business enterprises. In between those two landmark decisions, the Court concluded in Fitzpatrick $v$. Bitzer that the enforcement power was sufficient, when expressly employed, to override even the states' sovereign immunity reserved by the Constitution itself. Thus, the enforcement power represents a potent weapon for federal intervention in state government, lim-

83 Katzenbach v. Morgan, 384 U.S. at 651 (quoting South Carolina v. Katzenbach, 383 U.S. 301, 326 (1966)).

8417 U.S. (4 Wheat) 316 (1819).

85 Katzenbach v. Morgan, 384 U.S. at 653.

86400 U.S. 112 (1970).

87 Id. 117-18 (Black, J.). Justices Douglas, Brennan, White, and Marshall would have held that Congress may set the voting age in all elections. Chief Justice Burger and Justices Harlan, Stewart, and Blackmun believed that Congress could not legislatively control voter qualifications at all.

88448 U.S. 448 (1980). Chief Justice Burger wrote a plurality opinion for himself and Justices White and Powell. Justice Marshall, joined by Justices Brennan and Blackmun, concurred in the result. 
ited only by the broad two-step inquiry developed in Morgan and reiterated by the Fullilove plurality. ${ }^{89}$

\section{The Enforcement Power and Rights Not Guaranteed by the Constitution}

Despite the enforcement power's broad scope and the vagueness of the limits on its use, one question remains particularly troubling. That is the inquiry whether Congress may use the power to protect, or create, rights not explicitly granted by the Constitution.

It is noteworthy that the Court dealt with a related question in Morgan. Justice Harlan, in dissent, suggested that the "fundamental issue [is] whether in fact the state [practice or] enactment violates federal constitutional rights." 90 He therefore suggested that section 5's scope extended only to state action determined by the courts to violate the fourteenth amendment.

The Court firmly rejected that argument.91 In fact, it explicitly refused to consider whether the literacy requirement violated the equal protection clause, limiting its inquiry to whether the legislation was appropriate to enforce the clause. ${ }^{92}$

This prompted Professor Cox to conclude that the Court had explicitly held that Congress could, under the enforcement power, prohibit state practices which did not themselves violate the fourteenth amendment. ${ }^{83}$ The Court seems to agree. ${ }^{94}$

In City of Rome $v$. United States, ${ }^{95}$ the Court reiterated its holding in Morgan by stating that legislation enacted under the

$89 \mathrm{Id}$. 473. The plurality inquired whether "the objectives of this legislation are within the power of Congress." Id. (emphasis in original). It then assessed whether the means employed were constitutionally permissible for achieving Congress's objectives.

90384 U.S. at 670 (dissenting opinion). Justice Stewart joined the opinion.

91 Id. 648-49.

92 Id. 649-50.

93 Cox, supra note 78, at 107-08.

94 See Morgan, 384 U.S. at 668 (Harlan, J., dissenting) ("in effect the Court reads $\S 5$ of the Fourteenth Amendment as giving Congress the power to define the substantive scope of the Amendment") (emphasis in original); see also City of Rome v. United States, 446 U.S. 156, 177 (1980) ("It is clear, then, that under [the enforcement clause] of the Fifteenth Amendment Congress may prohibit practices that in and of themselves do not violate $\$ 1$ of the Amendment ...."); id. 207 n.1 ("[T] The nature of the enforcement powers conferred by the Fourteenth and Fifteenth Amendments has always been treated as coextensive") (Rehnquist, J., dissenting); Beer v. United States, 425 U.S. 130, 149 n.5 (1976) ("We have recognized that $\$ 5$ of the Fourteenth Amendment gives Congress the power to expand the substantive reach of the Amendment. Katzenbach v. Morgan.") (Marshall, J., dissenting); cf. Morgan, 384 U.S. at 651 (test for employment of enforcement powers same regardless whether fourteenth or fifteenth amendments involved).

95446 U.S. 156 (1980). 
enforcement power "would be upheld so long as that Court could find that the enactment 'is plainly adapted to [the] end' of enforcing the Equal Protection Clause and is not prohibited by but is consistent with "the letter and spirit of the constitution." " 86 In a highly significant addition to this restatement of the Morgan test, the Court stated that this is so "regardless of whether the practices outlawed by Congress in themselves violated the Equal Protection Clause." ${ }^{97}$ The Court supported this conclusion by pointing out that "correctly viewed, $\S 5$ is a positive grant of legislative power authorizing Congress to exercise its discretion in determining whether and what legislation is needed to secure the guarantees of the Fourteenth Amendment." 98 This, in the understanding of both "liberal" and "conservative" Justices, answers the question whether Congress can use the enforcement power to expand the scope of the fourteenth amendment's substantive protection.

The question with respect to the Fees Act's constitutionality, therefore, is not whether Congress could include federal statutory and state pendent claims within the scope of fourteenth amendment protection. The Court's view on that inquiry seems settled. Instead, the question is whether fee awards in such cases are an "appropriate" means of achieving the permissible objective of enforcing the fourteenth amendment against the states. ${ }^{90}$

\section{The Appropriateness of Fees in Non-Civil-Rights Cases}

It can be argued that the Court's reasoning in Katzenbach $v$. Morgan ${ }^{100}$ effectively forecloses consideration of the appropriateness of a statute enacted pursuant to the enforcement power provided the law meets a "rationality" standard.101 This argument is reinforced by the Court's dicta in Maher $v$. Gagne ${ }^{102}$ to the effect that Congress was acting appropriately in authorizing fees in a case involving a statutory non-civil-rights claim pendent to a "substan-

${ }^{96} \mathrm{Id}$. 176 (quoting Morgan, 384 U.S. at 651 (quoting McCulloch, 17 U.S. (4 Wheat.) at 421$)$ ).

o7 Id. 176.

$98 \mathrm{Id}$. (quoting Morgan, 384 U.S. at 651 ).

90 See Fullilove v. Klutznick, 448 U.S. 448, 476 (1980) (plurality opinion); supra text following note 84 .

100384 U.S. 641 (1966). See supra text accompanying notes 80-85.

101 See Katzenbach, 384 U.S. at 651-57; id. 656 (" $[I]$ t is enough that we perceive a basis upon which Congress might predicate [its] judgment.... ."); id. 653.

102448 U.S. 122 (1980).

103 Id. 132. 
tial" constitutional claim, ${ }^{103}$ and by the Court's endorsement of the Second Circuit's equally broad reasoning. ${ }^{104}$

But this position sweeps overly broadly, including within the ambit of "appropriateness" not only statutory and pendent claims attached to constitutional rights but statutory non-civil-rights claims asserted through section 1983 or standing alone. Yet the Court expressly left open in Maher the question whether such claims could support fee awards. ${ }^{105}$

Resolution of that question requires consideration of the vari: ous arguments about whether sovereign immunity bars a fee award in these cases. If so, the Fees Act could not be "appropriate" legislation in such cases for enforcing the fourteenth amendment.

\section{Arguments Against A Sovereign Immunity Bar}

Only one court has considered the question left open by Maher v. Gagne. In Southeast Legal Defense Group v. Adams, ${ }^{106}$ plaintiffs challenged the construction of a highway based on the due process and equal protection clauses and on various state and federal statutory grounds asserted through section 1983. The district court entered judgment for the plaintiffs on a claim under the Federal-Aid Highway Act, ${ }^{107}$ dismissed the remaining claims as moot, and awarded fees. The court reasoned that the constitutional claims were "not insubstantial," 108 meeting the Hagans v. Lavine ${ }^{109}$ test, and that the constitutional and Highway Act claims arose from a "common nucleus of operative fact," 110 meeting the United Mine Workers $v$. Gibbs 111 test. Thus, on the basis of footnote 7 of the House Report accompanying the Fees Act, ${ }^{112}$ the court awarded fees.

104 Id. 127 n.9.

105 Id. 130.

108657 F.2d 1118 (9th Cir. 1981). For a similar holding, see Morgan v. McDonough, 511 F. Supp. 408 (D. Mass.), affd mem., No. 80-1746 (1st Cir. June 30, 1981).

10728 U.S.C. $\$ 128(a)$ (1976). See Southeast Legal Defense Group v. Adams, 436 F. Supp. 891, 894-95 (D. Or. 1977), aff'd, 657 F.2d 1118 (9th Cir. 1981).

108436 F. Supp. at 894-95.

100415 U.S. 528 (1974). Hagans defined insubstantial as "essentially fictitious," "wholly insubstantial," "obviously frivolous," and "obviously without merit." Id. 537 (citations omitted).

110436 F. Supp. at 894-95.

111383 U.S. 751 (1966). See supra text accompanying notes 10-12.

112 H.R. Rep. No. 1588, 94th Cong., 2d Sess. 4 n.7 (1976). See supra text accompanying note 33 . 
The court of appeals affirmed. Relying on Maine $v$. Thiboutot, ${ }^{113}$ the court held that section 1983 was a proper vehicle for asserting the Highway Act claim. Again relying on Thiboutot, the court then concluded that the Fees Act "authorize[s] an award of attorneys fees in a $\S 1983$ action based upon a statutory, nonconstitutional claim." 114

Having concluded that the Act permitted fees, the court was required to consider whether the eleventh amendment barred the fee award in spite of the legislature's attempted authorization. Repeating the Supreme Court's discussion of statutory claims in Maher, the Ninth Circuit rested its affirmance on the Hagans and Gibbs tests, and on footnote 7.115

Thus, the court did not resolve the question left open by Maher in its holding. The question reserved in Maher was whether fees could be awarded "based on a statutory non-civil-rights claim." ${ }^{116}$ The Ninth Circuit concluded in dicta that fees were authorized in such a case, but it rested its decision on the Gibbs test and the "substantiality" of the attached, but unresolved, constitutional claim. ${ }^{117}$

Nevertheless, Adams effectively answers the question reserved in Maher by expanding fee awards to cases involving procedural rather than substantive due process claims. It will be a rare case when plaintiffs cannot construct a "substantial" procedural due process claim within the Hagans Court's definition of that word.118

113448 U.S. $I$ (1980). See stpra text accompanying notes 22-26.

114657 F.2d at 1123 (emphasis added).

$115 \mathrm{Id}$. 1124-25.

116448 U.S. at 130 .

117657 F.2d at 1124-25 ("The district court . . . found plaintiffs" constitutional claims to be substantial and found that the . . claims arise- out of a "common nucleus of operative fact.' We agree with the district court."). See Morgan v. McDonough, 511 F. Supp. 408 (D. Mass.), aff'd mem., No. 80-1746 (1st Cir. June 30, 1981) (same); of. Milwe v. Cavuto, 653 F.2d 80, 84 (2d Cir. 1981) (court concludes in dicta that Maher justifies fee award in favor of plaintiff prevailing on state pendent claim).

118 The Hagans test for substantiality eliminates only claims that are "obviously frivolous." See supra note 109.

The constitutional claim in Adams was a due process argument based on "inadequate notice and failure to conduct [a] hearing so as to allow for meaningful public comment." 657 F.2d at 1125. The court noted that such "[a] violation . . . is a distinct possibility whenever a right to a hearing is abrogated . ..." Id.

Thus, the court did not distinguish between substantive and procedural due process claims. It is interesting to note that in other contexts involving $\$ 1983$ claims, the Supreme Court has made that distinction. See Parratt v. Taylor, 101 S. Ct. 1908, I914 (1981); id. 1918 (White, J., concurring); id. (Blackmun, J., concurring); $i d .1922$ (Powell, J., concurring in the result); Carey v. Piphus, 435 U.S. 247,265 (1978). 
According to Adams, such a claim guarantees fees if the plaintiffs prevail on any related issue.

This bootstrap rationale for overcoming the sovereign immunity bar is at once expanded and explained by the argument that the enactment of the fourteenth amendment signified a "repeal" of the eleventh amendment. This view holds that because the eleventh amendment cloaks the state with a constitutional immunity, only constitutional action can overcome that immunity. Section 5 is that constitutional action, giving Congress the power to legislatively authorize otherwise impermissible actions against the states. Under this view, the Fees Act, in which Congress made its intention to abrogate immunity sufficiently explicit for the Supreme Court, overrides eleventh amendment immunity in every case.119 This position, then, makes Congress itself the arbiter of what is "appropriate" legislation under section 5. In that respect it reflects the Court's view in Katzenbach $v$. Morgan ${ }^{120}$ and subsequent section 5 cases. $^{121}$

In Peel v. Florida Department of Transportation, ${ }^{122}$ a panel of the Fifth Circuit considered this position. The court's approach to the argument was somewhat opaque, for it seemed to reject the suggestion that section 5 flatly overturned the eleventh amendment.123 Yet it held that the critical inquiry in these cases was Congress's intent, for "Congress still need[s] intentionally to abrogate the state's eleventh amendment immunity .... Thus ... the eleventh amendment could still bar suit in federal court where Congress ha[s] acted under section 5 . The inquiry ... [is] how clearly Congress ... intended to abrogate the state's eleventh amendment immunity." 124

It seems that the court rejected the repeal argument in one breath and accepted it in the next. For the recognition that Congress can override immunity if it intends to do so means that the court concluded that there was no longer a constitutional bar to suits against the state. This must be so because Congress cannot

119 See Hutto v. Finney, 437 U.S. 678, 693-94 (1978).

120 " $\$ 5$ is a positive grant of legislative power authorizing Congress to exercise its discretion in determining whether and what legislation is needed to secure the guarantees of the Fourteenth Amendment." 384 U.S. at 651 (emphasis added).

121 See supra text accompanying notes 86-99.

122600 F.2d 1070 (5th Cir. 1979).

123 See id. 1078 (Supreme Court's approach to $\$ 5$ goes "beyond mere statutory interpretation").

124 Id. 1078 (emphasis in original). See Quern v. Jordan, 440 U.S. 332, 342-46 (1979) ( $\$ 1983$ and abrogation of sovereign immunity). 
legislatively "abrogate" a provision of the constitution ${ }^{125}$ unless some other constitutional provision gives Congress authorization. Thus, by authorizing legislation that has the effect of overriding the eleventh amendment, section 5 must repeal that amendment to the extent that the two are inconsistent.

Other arguments against an eleventh amendment barrier to fees focus on section 5's purpose of requiring the states to conform their behavior to the commands of section 1 of the fourteenth amendment. ${ }^{128}$ It can be argued that this purpose cannot be carried out without fee awards in pendent and statutory claim cases because, with plaintiffs limited to injunctive relief, there is no incentive to sue states and require them to honor the fourteenth amendment's commands. ${ }^{127}$

Professor Nowak expressed a similar point by stating: "The drafters of the fourteenth amendment would, thus, not have tolerated a position which denied Congress the power to create private causes of action enforceable in federal courts against states which refused to extend protection to the rights embodied in section 1 of the amendment." 128 Of course, section 1983 does not create a cause of action-it merely provides a remedy for enforcement of constitutional and statutory provisions. ${ }^{129}$ But it is easy to analogize Nowak's position to the fee context. For if Congress can create causes of action under section 5 , then it can surely aid the enforcement of these causes of action by permitting a fee award.

This argument assumes that federal statutory and state pendent claims actually force states to comply with the equal protection and due process clauses. To support this position in every case-for the legislative history of the Fees Act forecloses the argument that Congress meant fees and sovereign immunity to depend on the nature of the right asserted determined on a case-by-case basis ${ }^{130}$-it is

125 Marbury v. Madison, 5 U.S. (1 Cranch) 137 (1803).

126 See Katzenbach v. Morgan, 384 U.S. at 648 n.8 (quoting Cong. Grobe, 39th Cong., 1st Sess. 2766, 2768 (1866) (Statement of Sen. Howard)).

127 See Field, The Eleventh Amendment and Other Sovereign Immunity Doctrines: Congressional Imposition of Suit Upon the States, 126 U. PA. L. REv. 1203, 1238-39 (1978) ("[C]ongressional authorizations of suit are meaningful only if they make available some [damage] remedy.").

128 Nowak, The Scope of Congressional Power to Create Causes of Action Against State Governments and the History of the Eleventh and Fourteenth Amendments, 75 Colum. L. Rev. 1413, 1463 (1975).

129 Chapman v. Houston Welfare Rights Org., 441 U.S. 600, 617-18 (1979).

130 See Maine v. Thiboutot, 448 U.S. 1, 9-10 \& n.7 (1980). 
necessary to invoke the prophylactic rationale of South Carolina $v$. Katzenbach ${ }^{131}$ and Katzenbach v. Morgan. ${ }^{132}$

That view suggests that Congress may prohibit as a precautionary measure any practice lending itself to fourteenth amendment violations. On this theory, violations of federal statutes or state law by state officials, while not reaching the level of constitutional deprivations, nevertheless involve state-sponsored abuses of individual rights. ${ }^{133}$ If unchecked, these abuses will lead to future violations that will ultimately reach the level of fourteenth amendment violations. ${ }^{134}$

In other words, the difference between police negligence and police brutality is only a matter of degree, and Congress, in its discretion under section 5 about what measures are appropriate to enforce the fourteenth amendment, is privileged to outlaw the lesser offense in order to avoid the greater. ${ }^{135}$ Accepting this theory, fee awards against the state are vital in order to make it worthwhile for plaintiffs to sue, preventing further, and future, abuses. This view permits fees whenever plaintiffs prevail on a statutory or pendent claim which presents a likelihood of future, possibly constitutional, violations.

A related argument suggests that section 5's purpose is to enlarge federal court jurisdiction to protect "civil rights." ${ }^{138}$ Whether

131383 U.S. 301 (1966). This case upheld the constitutionality of the Voting Rights Act of 1965, Pub. L. No. 89-110, 79 Stat. 437 (codified at 42 U.S.C. $\$ 1973$ to 1973aa-5 (1976)), under the enforcement power of the fifteenth amendment. U.S. CoNst. amend. XV, \$2.

132384 U.S. 641 (1966). See supra text accompanying notes 80-85.

133 See Katzenbach v. Morgan, 384 U.S. at 653 ("[The statute] enables the minority better to obtain perfect equality of civil rights and the equal protection of the laws." ); id. 649 ("Without regard to whether the judiciary would find that the Equal Protection Clause itself nullifies [the] literacy requirement ...., could Congress prohibit the enforcement of the state law by legislating under $\$ 5$ ... ?") (emphasis added); cf. id. 648 ("A construction of $\$ 5$ that would require a judicial determination that the enforcement of the state law ... violated the Amendment ... . would depreciate both congressional resourcefulness and congressional responsibility for implementing the Amendment.") (footnote omitted). The omitted footnote is instructive about Congress's view of section 5's purpose. Id. n.8.

134 Compare Russo v. New York, 515 F. Supp. 470 (S.D.N.Y. 1981) (malicious prosecution claim essentially establishes elements of fourteenth amendment claim) with Meriwether v. Sherwood, 514 F. Supp. 433 (S.D.N.Y. 1981) (negligence and malpractice claims do not establish elements of fourteenth amendment claim). 135 See supra note 120.

-As for the difference-or lack of it-between police brutality and negligence, see Hays v. Jefferson County, Nos. 80-3010, -3011 (6th Cir. Jan. 4, 1982) (negligent failure to train police does not make supervisors liable for $\$ 1983$ claim of police brutality). But see Parratt v. Taylor, I01 S. Ct. 1908 (1981) (negligent deprivation states a cause of action under $\S 1983$ ).

136 Nowak, supra note 128 , at 1463. 
those rights are "privileges of [being] citizen[s]," ${ }^{127}$ or whether they are only laws insuring equality, ${ }^{138}$ violations of civil rights requires an incentive to make use of federal jurisdiction. Knowing that they cannot recover damages from the state, plaintiffs are unlikely to bear the expense of suing for injunctive relief without the assurance that, if successful, they will not have to bear counsel fees.

The weakness of this argument is that a permissive grant of jurisdiction is not the same as a requirement that federal courts hear the case. This is especially true when, as in state pendent claim cases, the jurisdiction is judicially created. Furthermore, the Court's decision in Chapman v. Houston Welfare Rights Organization ${ }^{139}$ makes it clear that jurisdiction over claims under section 1983 does depend on the nature of the right being enforced. Thus, "pure" civil rights statutory claims are jurisdictional under section $1343(3)$; statutory non-civil-rights claims are jurisdictional only under section 1331. ${ }^{140}$ The Court rejected this distinction for fees purposes in Maine $v$. Thiboutot, ${ }^{141}$ but such a distinction could be resurrected for sovereign immunity cases.

In short, the "repeal" and prophylactic rationales for overcoming sovereign immunity present the most compelling arguments for fees awards in statutory and pendent claim cases. Each of these theories, explicitly or implicitly, has gained acceptance in federal courts.

\section{Arguments for A Sovereign Immunity Bar}

The first argument that sovereign immunity bars a fee award in pendent and statutory claim cases is that Congress, even though acting pursuant to section 5, cannot "incorporate" nonconstitutional rights into the fourteenth amendment. This contention seems foreclosed by the views expressed by several members of the Court. ${ }^{142}$ It is worth noting, however, that the Court has expressed the view that congressional power under section $\mathbf{5}$ is limited to "adopting measures to enforce the guarantees of the [fourteenth] amend-

137 Oregon v. Mitchell, 400 U.S. 112, 163 (1970) (Harlan, J.).

138 See id. 150-52 (Appendix to Opinion of Douglas, J.) (list of cases striking down statutes not discriminating on the basis of race under the equal protection clause).

13944 U.S. 600 (1979). See Maher, 448 U.S. at 129 n.11 (distinguishing $\$ 1988$ from $\$ 1343$ ).

140441 U.S. at 615-20.

141448 U.S. 1 (1980).

142 See supra text accompanying notes 90-98. 
ment." 143 There may, therefore, be some uncertainty in the view that Congress may expand the fourteenth amendment's substantive reach by using the enforcement power.

The second argument is that a fee award, no matter how described, violates two tenets of the eleventh amendment. First, it permits the imposition of direct-not ancillary-burdens on the :state treasury. ${ }^{\mathbf{1 4 4}}$ Second, it permits a retroactive monetary award against the state. ${ }^{145}$ These potential problems are of no concern if eleventh amendment immunity is in fact abrogated, so constitutional claims and claims under statutes providing for equal rights present no eleventh amendment difficulty. But in pendent and statutory non-civil-rights claim cases, where Congress's intention is not so clearly expressed, courts should be hesitant to award relief that would otherwise be barred.148

The Court in Hutto $v$. Finney ${ }^{147}$ addressed and rejected both of these arguments. It held that fees were not retroactive awards for prelitigation conduct, but for "expenses incurred in litigation seeking only prospective relief." 148 With respect to the burden on the state treasury, the Court held that because fees are awarded as part of costs, they are an ancillary burden to litigation..$^{149}$

The third argument for sovereign immunity is based upon the jurisdictional statutes and the decision in Chapman $v$. Houston Welfare Rights Organization. ${ }^{150}$ In Chapman, the Court held that section 1983, through which all statutory fee claims are asserted, was enacted to "ensur[e] a right of action to enforce the protections of the Fourteenth Amendment and federal laws enacted pursuant thereto." 151 Because statutory claims that do not.protect equal

143 Katzenbach v. Morgan, 384 U.S. at 651 n.10.

144 Nowak, supra note 128, at 1444. See Keith v. Volpe, 501 F. Supp. 403 (C.D. Cal. 1980) ( $\$ 2.2$ million fee award against state).

145 Nowak, supra note 128, at 1464.

146 See supra note 60.

147437 U.S. 678 (1978).

$148 \mathrm{Id} .695$ \& $\mathrm{n} .24 ;$ id. $698 \mathrm{n} .31$ (discussing retroactive liability issue "[I]f we were not dealing with an item such as costs ....").

140 See Senate Report, supra note 6, at 5, reprinted in 1976 U.S. Code Cong. \& AD. News 5908, 5913 ("ancillary"); Hutto v. Finney, 437 U.S. at 697 n.27 ("[A]n award of costs . . . could hardly create an [enormous fiscal burden] for a State."). But see Keith v. Volpe, 501 F. Supp. 403 (C.D. Cal. 1980) (\$2.2 million award).

150441 U.S. 600 (1979).

151 Id. 611 (emphasis added). 
rights, like the Social Security Act claim in Chapman, are not enacted pursuant to the fourteenth amendment, they are not within the "pure" scope of section 1983. Thus, a fee award in such cases distorts the purpose of section 1983 and of the Fees Act.

However plausible such an argument sounds, it runs squarely into the Court's decision in Thiboutot. For if section 1983 encompasses all statutory claims, the "civil-rights"-"non-civil-rights" distinction in Chapman would make the fee award dependent on the nature of the right asserted. This result would run counter to the purposes of the Act and to the decision in Thiboutot. ${ }^{152}$

A similar argument stems from the Chapman Court's holding that there is no such thing as a suit for "violation" of section 1983 because that statute provides only a remedy and not a substantive right. ${ }^{153}$ This led the Court to conclude that section 1343(3), the jurisdictional counterpart of section 1983, did not confer federal jurisdiction when section 1983 was used to remedy a violation which did not involve a statute providing for equal rights. ${ }^{154}$

Thus, the argument claims that, in statutory and pendent claim cases, fees are a remedy not for a substantive violation but for the use of another remedial statute. This bootstrap abrogation of immunity allows an award against the state even though neither the federal statutory or state pendent substantive ground, nor the statute providing federal jurisdiction, abrogate that immunity by themselves.

A federal district court recently relied on this bootstrap argument to deny fees in a statutory case asserted through section 1983.155 It is significant, however, that the court did not rely on sovereign immunity in refusing the award. Rather, it held that as a matter of discretion, it would not award fees when section 1983 was used merely as a "conduit" for a nonfee claim..

Finally, there is the argument that allowing sovereign immunity to be abrogated by a pendent claim "repeals" the eleventh amendment in almost every case. Under this view, allowing jurisdiction over claims tied to constitutional allegations-many of which will

152 See 448 U.S. at 9-10.

$15344 I$ U.S. at $617-18$.

154 Id. 618.

105 Tatro v. Texas, 516 F. Supp. 968 (N.D. Tex. 1981). The case involved a claim under the Education of All Handicapped Children Act, 20 U.S.C.A. $\$$ 14111420 (1978 \& Supp. 1981). The court refused to award fees because it held that section 1983 could have no greater role in the outcome of a lawsuit than the statute it enforces.

108516 F. Supp. at 984. 
never be resolved by the federal court-essentially permits federal judges to abrogate sovereign immunity at their discretion. The point becomes particularly clear if fee awards are permitted in state pendent claim cases. Then federal courts set aside immunity merely by accepting jurisdiction over a pendent claim. This is so even if the underlying constitutional claim is not reached. Because of the ease with which pendent claims can be attached to "nonfrivolous" constitutional claims, ${ }^{157}$ district judges may be required to refuse to hear pendent claims in order to avoid the immunity question.

If federal courts use discretion not to hear pendent claims in potential fee cases, plaintiffs are required either to split their claims between state and federal court or to bring the entire claim in state court. The latter undermines the notion that plaintiffs have a right to a federal forum for their federal claims; ${ }^{158}$ the former exacts additional costs from litigants and wastes judicial resources. ${ }^{169}$ Furthermore, even assuming that plaintiffs will take their claims to state courts, they will presumably ask those courts for fees-as did the plaintiffs in Thiboutot-or return to the federal court after state litigation is completed to request a fee award.

\section{E. Summary}

The interaction between the enforcement power and the eleventh amendment is nowhere more puzzling than when Congress acts to expand the substantive protections of the fourteenth amendment. The issue of fee awards in cases involving pendent and statutory non-civil-rights claims squarely presents the enforcement power and sovereign immunity conflict.

157 See Chapman v. Houston Welfare Rights Org., 441 U.S. at 675 (Stewart, J., dissenting); Bond v. Stanton, 630 F.2d 1231, 1236 n.5 (7th Cir. 1980) ("Moreover, plaintiffs also initially asserted in their complaint an arguably substantial constitutional claim under the fourteenth amendment, which, although never decided, was arguably sufficient to ... bring the ... action within the ambit of Section 1983.") (emphasis added).

158 See England v. Louisiana State Bd. of Medical Exams., 375 U.S. 411, 415 (1964); Monroe v. Pape, 365 U.S. 167, 180 (1961); Moore v. El Paso County, 660 F.2d 586, 591 n.7 (5th Cir. 1981) ("right to a federal forum"). But see Allen v. McCurry, 449 U.S. 90, 103 (1980) (no right to unencumbered opportunity to litigate federal claim in district court); Lehman v. Lycoming County Children's Servs., 648 F.2d 135, 144 (3d Cir. 1981) (en banc) (no "right [to have a federal court consider federal claims] exists.") (plurality opinion); Whitman, Constitutional Torts, 79 MrCH. L. Rev. 5, 25 (1980) (broad reading of $\$ 1983$ “displaces state lawmaking authority by diverting decisionmaking to the federal courts").

150 For example, the policies underlying Gibbs are judicial economy, convenience, and fairness to the litigants. See 383 U.S. at 725; supra notes 10-12 and accompanying text. See also Railroad Comm'n v. Pullman Co., 312 U.S. 496, 500 (1941) ("avoid the waste of a tentative decision ...."). 
The arguments that sovereign immunity does not bar fee awards in these cases essentially focus on section 5's purpose and on its implied repeal of the eleventh amendment. The arguments that sovereign immunity bars a fee award are essentially reduced by decisions of the Supreme Court to the "bootstrap" argument.

This Comment now considers two rationales that avoid the immunity question in pendent and statutory claim cases. The Comment then concludes with an analysis of the relative merits of the arguments for and against a sovereign immunity barrier to fees in such cases.

\section{Conclusion}

\section{A. Fees as Costs}

Justice Stevens's separate opinion in Fitzpatrick $v$. Bitzer ${ }^{160}$ advanced the argument that fees should be awarded against states without consideration of the eleventh amendment. He suggested that fees should be treated as litigation costs, which are traditionally awarded against states because costs are "incident to litigation" and not "retroactive relief." 161

The position that fees should be treated as costs gained majority support in Hutto v. Finney ${ }^{162}$ and Maher $v$. Gagne. ${ }^{103}$ The Court's reasoning was based on prior precedent holding that costs could be awarded against states ${ }^{164}$ and on Congress's expressed intention that fees under the Act were to be awarded "as part of the costs." 165 This, in the Court's view, rendered sovereign immunity inapplicable.

The fees as costs rationale has gained wide adherence in the courts of appeals. ${ }^{168}$ None of these courts has been persuaded by the four Hutto dissenters' argument that counsel fees have not "been part of the routine litigation expenses assessed against parties

160427 U.S. 445,458 (1976) (concurring in the judgment).

161 Id. 460.

162437 U.S. 678 ( 1978 ).

163448 U.S. 122 (1980).

164 See Hutto v. Finney, 437 U.S. at 695-97; Fairmont Creamery Co. v. Minnesota, 275 U.S. 70 (1927); North Dakota v. Minnesota, 263 U.S. 583 (1924).

165 Hutto, 437 U.S. at 695 (quoting 42 U.S.C. $\$ 1988$ (1976)).

${ }^{166}$ See, e.g., Fernandes v. Limmer, No. 79-3581 (5th Cir. Dec. 11, 1981); Bond v. Stanton, 630 F.2d 1231, 1234 (7th Cir. 1980); Williams v. Alioto, 625 F.2d 845, 848 (9th Cir. 1980) (per curiam), cert. denied, 450 U.S. 1012 (1981); Wisconsin Socialist Workers 1976 Campaign Comm. v. McCann, 460 F. Supp. 1054 (E.D. Wis. 1978) (three-judge court); of. Weisenberger v. Huecker, 593 F.2d 49,52 n.7 (6th Cir.) (describing costs as alternative holding and overruling inconsistent cases), cert. denied, 444 U.S. 880 (1979). 
in American courts." 187 Despite the dissenters' additional argument that fees are "not intimately related to the mechanics of litigation," 168 courts have granted substantial fees on the costs rationale and without regard to sovereign immunity.

One argument against the costs rationale is that if Congress has the power to determine what litigation expenses are to be treated as costs, then the eleventh amendment can be overcome merely by designating any monetary award permitted by statute to be assessed against the states as a "cost." The Hutto Court expressly protected itself against this eventuality, however, by stating that the rationale did not necessarily apply to all cases in which Congress designated monetary awards as "costs." 169

The second argument against the costs rationale is that it provides no principled reason for leaving open the question in Maher whether fees can be awarded in statutory, non-civil-rights cases. For if fees are merely costs in cases involving constitutional claims, then they should likewise be costs in every case. The Court may adopt this position in a future case; until it does, however, there is no basis for suggesting that the costs rationale necessarily avoids the sovereign immunity problem.

\section{B. Reaching the Underlying Claim}

In cases in which plaintiffs prevail on constitutional or statutory civil rights claims, Hutto and Maher establish that fee awards are not barred by sovereign immunity. In cases in which plaintiffs prevail on statutory non-civil-rights or state pendent claims, a court could avoid sovereign immunity by deciding the underlying constitutional or civil rights claim.

The legislative history of the Fees Act indicates that Congress. intended courts to follow this course. ${ }^{170}$ But since the decision in Siler $v$. Louisville of Nashville Railroad, ${ }^{171}$ it has been a principle of

167437 U.S. at 707 (Powell, J., dissenting).

168 Id.

169 "Thus we do not suggest that our analysis would be the same if Congress were to expand the concept of costs beyond the traditional category of litigation expenses." Id. 697 n.24.

170 To the extent a plaintiff joins a claim under one of the statutes enumerated in H.R. 15460 with a claim that does not allow attorney fees, that plaintiff, if it prevails on the non-fee claim, is entitled to a determination on the other claim for the purpose of awarding counsel fees.

H.R. REp. No. 1558, 94th Cong., $2 d$ Sess. 4 n.7 (1976).

171213 U.S. 175 (1909). See Railroad Comm'n v. Pullman Co., 312 U.S. 496 (1941). 
judicial restraint that courts should avoid deciding constitutional questions when other dispositive grounds are available. This, however, is a judicially-created rule and not a constitutional doctrine. ${ }^{172}$

Reaching the underlying claim avoids the sovereign immunity question in all cases in which a constitutional or statutory civil rights claim exists, for if that underlying claim is resolved in the plaintiff's favor, fees are appropriate under Hutto and Thiboutot. If the plaintiff loses on the underlying claim, fees would not be awarded because the plaintiff would not be a prevailing party under the Fees Act. ${ }^{178}$ Thus, in Southeast Legal Defense Group $v$. Adams, ${ }^{174}$ this approach would have required the court to reach the procedural due process claim and would have avoided both the sovereign immunity problem and the incongruousness of resting a fee award on the Federal-Aid Highway Act. ${ }^{175}$

As a practical matter, this approach would resolve nearly every fees case. This is so because most cases involve some constitutional claim, and, for those which do not, it is not difficult to construct such a claim.176 Rather than permitting a court to award fees merely by mouthing the "substantiality" test of Hagans $v$. Lavine,,$^{177}$ resolving the underlying claim would require courts to examine the merits of the civil rights claim in order to justify a fee award.

This approach is commendable because it vindicates the Act's purpose of allowing litigants with federal claims access to federal

172 Justice Brandeis explained that the Siler rule is not constitutionally required, but was developed by the Court "for its own governance in cases confessedly within its jurisdiction ...." Ashwander v. Tennessee Valley Auth., 297 U.S. 288, 346 (1936) (concurring opinion).

173 See supra note 4. text.

174657 F.2d 1118 (9th Cir. 1981). See supra notes 106-18 and accompanying

175 It is important to note that there is no requirement that plaintiffs win damages in order to receive fees. Thus, courts reaching the underlying constitutional claim solely for the purpose of deciding whether to award fees will not have to calculate damages. This is so because all that the statute requires is that the plaintiff be a "prevailing party," 42 U.S.C. \$1988 (1976) (emphasis' added), and courts have interpreted this phrase to permit a fee award even when the plaintiff recovers only nominal damages. Milwe v. Cavuoto, 653 F.2d 80, 84 (2d Cir. 1981); Perez v. University of Puerto Rico, 600 F.2d 1, 2 (1st Cir. 1979); see Carey v. Piphus, 435 U.S. 247, 257 n.I1 (1978). But see Huntley v. Community School Bd., 579 F.2d 738, 742 (2d Cir. 1978) (per curiam) (no fees for "at most ... a moral victory ....").

176 See supra note 157.

177415 U.S. 528 (1974). See supra note 109. A stricter standard of "substantiality" might avoid many fee cases involving pendent and statutory claims by requiring plaintiffs to meet a greater burden in order to establish federal jurisdiction. The merits of adopting such a standard are beyond the scope of this Comment. 
courts, even when the state is a defendant. And plaintiffs who prevail against the state on the kind of claim that the fourteenth amendment explicitly protects-a constitutional or civil rights claim -will receive a fee award. Yet by resolving the underlying claim, courts prevent the'distortion of the Act's purpose that occur when plaintiffs who meet the loose United Mine Workers v. Gibbs ${ }^{178}$ and Hagans $v$. Lavine ${ }^{179}$ tests are permitted to receive fees in spite of the possible lack of merit of the underlying civil rights claim.

Furthermore, because reaching the underlying claim avoids a constitutional question of sovereign immunity, the Siler doctrine of avoiding the decision of unnecessary constitutional questions is arguably not offended. Even if Siler suggests that courts should not decide the underlying claim, Fees Act cases should be an exception to this judicially-created doctrine in order both to carry out the legislative intent and to avoid abuse of the easily satisfied Gibbs and Hagans tests.

\section{Sovereign Immunity}

If courts refuse to treat fees as costs or to reach the underlying claim, then they must decide the sovereign immunity question. The discussion of arguments for a sovereign immunity bar in part III reveals that most of those arguments have found no support in the courts. ${ }^{180}$ The exception is the bootstrap problem; but if federal courts believe that plaintiffs are asserting claims through section 1983 solely to seek fees, those courts can use their statutory discretion to refuse fee awards. ${ }^{181}$ This use of discretion prevents litigants from abusing the Act's purpose-as does reaching the underlying claim-and at the same time avoids reliance on a sovereign immunity barrier.

On balance, the arguments that sovereign immunity does not bar fee awards in these cases seem stronger than those favoring a bar. The "implied repeal" argument has been adverted to at least once by the Supreme Court. ${ }^{182}$ The broad purposes of section 5 have been the subject of most of the Court's decisions interpreting

178383 U.S. 715 (1966). See supra notes 10-12 and accompanying text.

179415 U.S. 528 (1974). See supra notes 157 \& 109.

180 See supra text accompanying notes 142-59.

181 See supra notes 153-56 and accompanying text.

182 See Hutto, 437 U.S. at 698 \& n.31. 
that section. ${ }^{183}$ Finally, Congress's broad powers under section 5 and the limited judicial review of exercises of that power are well established. ${ }^{184}$ Combined with the broad judicial interpretation of the Fees Act itself, ${ }^{185}$ the imposition of an immunity barrier to awards in cases involving statutory non-civil-rights and state pendent claims would be inappropriate.

183 See Fullilove v. Klutznick, 448 U.S. 448 (1980); Oregon v. Mitchell, 400 U.S. 112 (1970); Katzenbach v. Morgan, 384 U.S. 641 (1966); supra notes 90-99 and accompanying text.

184 See supra notes 78-89 \& 101; supra note 120 and accompanying text. 185 See supra text accompanying note 63. 